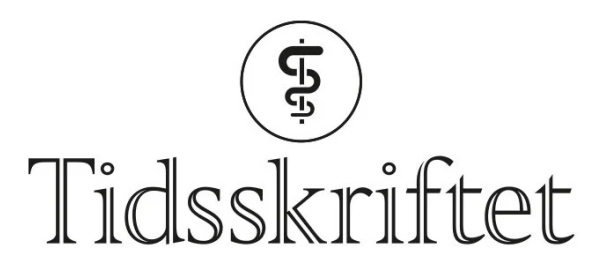

DEN NORSKE LEGEFORENING

\title{
Om vonde hendelser som påvirker smertetilstander
}

ANMELDELSER

PETTER C. BORCHGREVINK

Avdelingssjef, Avdeling for smerte og sammensatte lidelser

St. Olavs hospital

JANNE LUNDBOM

Fastlege, Hommelvik legesenter

Eline Thornquist, Anna Luise Kirkengen

Sammensatte lidelser

Et samfunnsspeil. 166 s. Bergen: Fagbokforlaget, 2020. Pris NOK 329

ISBN 978-82-450-3406-6

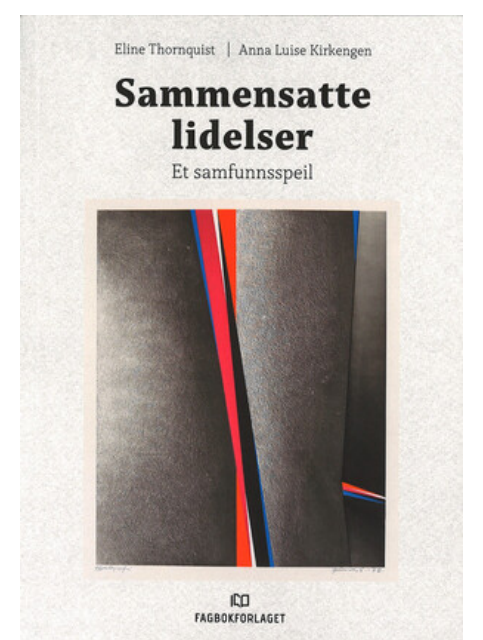

Formålet med boka er ifølge forfatterne «å utfylle epidemiologisk og annen statistikkbasert forskning om pasienter med kroniske og sammensatte lidelser». Det viktige de gjør i denne sammenhengen er å presentere et kvalitativt forskningsprosjekt om pasienter fra en smertepoliklinikk. Målgruppa er studenter i helse- og sosialfag og medisin, men kapitlene med dybdeintervjuene og analyse av disse vil også være verdt å lese for alle som undersøker 
og følger pasienter med sammensatte lidelser. Denne delen vil langt på vei kunne lykkes med det som står i invitasjonsbrevet til pasientene som blir intervjuet: «Et mål med studien er å øke behandlende personell sin kunnskap om hvordan vonde og vanskelige hendelser påvirker den enkelte.»

Det er tankevekkende å lese de nedskrevne intervjuene og analysene om pasientenes vurderinger av hvordan barndom, livserfaring, sosial status, kultur og måte å bli møtt på medvirker til, forsterker og vedlikeholder sammensatte smertetilstander. Selv om disse smertetilstandene ikke nødvendigvis kjennetegnes av vanskelig oppvekst og psykiske traumer, har alle de åtte pasientene opplevd slike hendelser som svært avgjørende for sykdomsutviklingen.

I de andre delene av boka er derimot ambisjonene om å «overskride kropp-sjel-dualismen» i overkant, noe forfatterne også delvis innrømmer. I disse kapitlene presenteres forståelsesrammen, fortolkningene og allmenne holdepunkter for terapeutisk praksis som om disse gjelder for hele den store, uensartede gruppa som kan betegnes å ha sammensatte lidelser. Det gis et inntrykk av at traumatiske hendelser kjennetegner alle disse pasientene med betydelige somatiske lidelser, der biopsykososiale faktorer er spesielt tett vevet sammen og ingen anerkjente diagnoser fullt ut kan forklare tilstanden.

Forfatterne lykkes heller ikke med «å knytte an til ny forskning», slik det står på baksideteksten. De henviser riktignok til mange klassiske studier, men de er slett ikke nye. Det er påfallende at det ikke i større grad henvises til den store mengden nye forskningsartikler som viser sammenheng mellom langvarige smertetilstander og psykososiale faktorer.

Vi vil allikevel anbefale boka. Utskriftene av intervjuene er svært lærerik lesing. De illustrerer at ensidig vektlegging på mestring av dagens utfordringer ikke alltid er det beste. Spesielt vil allmennleger og smerteklinikere ha mye å lære av hvordan forskeren intervjuer pasientene.

Publisert: 28. februar 2022. Tidsskr Nor Legeforen. DOI: 10.4045/tidsskr.21.0596

(C) Tidsskrift for Den norske legeforening 2023. Lastet ned fra tidsskriftet.no 26. april 2023. 